\title{
KORELASI ANTARA KECERDASAN INTERPERSONAL DENGAN HASIL BELAJAR IPS SISWA KELAS V DI SD GUGUS IV ABIANSEMAL TAHUN PELAJARAN2017/2018
}

\author{
I Dw. Kt. Artha Saputra ${ }^{1}$, I Wyn. Sujana ${ }^{2}$ I.B. Surya Manuaba ${ }^{3}$ \\ 1,2,3 Jurusan Pendidikan Guru Sekolah Dasar, Universitas Pendidikan Ganesha, Singaraja Jurusan, \\ Universitas Pedidikan Ganesha, \\ e-mail: saputra.dewa@undiksha.ac.id'1, \\ iwayan.sujana@undiksha.ac.id², idabagussurya.manuaba@undiksha.ac.id ${ }^{3}$
}

\begin{abstract}
Abstrak
Penelitian ini bertujuan untuk mengetahui korelasi yang signifikan antara kecerdasan interpersonal dengan hasil belajar IPS siswa kelas V di SD Gugus IV Abiansemal Tahun Pelajaran 2017/2018. Jenis penelitian ini adalah penelitian ex post facto dengan korelasi yang bersifat asimetris. Populasi dari penelitian ini merupakan siswa kelas V SD Gugus IV Abiansemal, Tahun Pelajaran 2017/2018 yang memiliki populasi 145 siswa. Penentuan sampel menggunakan teknik proporsional random sampling dengan taraf signifikansi $5 \%$ dan diperoleh banyak sampel dari populasi adalah 106 siswa. Data diperoleh dari pencatatan dokumen hasil belajar IPS dan pengisian angket kecerdasan interpersonal oleh responden. Sebagai uji prasyarat adalah uji normalitas sebaran data. Setelah terpenuhi prasyarat tersebut, berikutnya adalah uji hipotesis menggunakan analisis korelasi product moment. Berdasarkan hasil analisis maka $r_{x y \text { hitung }}=0,484$. Pada taraf signifikansi $5 \%$ dengan $\mathrm{n}=106$ maka diperoleh $r_{x y \text { tabel }}=0,195$. Karena $r_{x y \text { hitung }}>r_{x y \text { tabel }}=0,484>0,195$ maka dapat diartikan bahwa $H_{0}$ yang berbunyi tidak terdapat hubungan yang signifikan antara kecerdasan interpersonal dengan hasil belajar IPS siswa kelas V di SD Gugus IV Abiansemal Tahun Pelajaran 2017/2018 ditolak dan $H_{a}$ diterima. Jadi dapat disimpulkan bahwa terdapat korelasi yang signifikan antara kecerdasan interpersonal dengan hasil belajar IPS siswa kelas V di SD Gugus IV Abiansemal Tahun Pelajaran 2017/2018, dengan arah korelasi positif, artinya semakin tinggi kecerdasan interpersonal maka semakin tinggi pula hasil belajar IPS yang diperoleh siswa.
\end{abstract}

Kata kunci: kecerdasan interpersonal, hasil belajar, ilmu pengetahuan sosial (IPS)

\begin{abstract}
The research was aimed at determining the significant correlation between the interpersonal intelligence and the social science learning achievement of the fifth-grade students in Elementary School of Gugus IV Abiansemal in the academic year 2017/2018. The type of this research was expost facto using asymmetric correlation. The population of this research was the fifth-grade students of Elementary School Gugus IV Abiansemal in the academic year 2017/2018 which consisted of 145 students. The sample was decided by the proportional random sampling technique in which the significance level was $5 \%$ and 106 students were obtained from the population. The data collection was conducted through the documentation of students' learning achievement in social science and the questionnaire about the students' interpersonal intelligence. The prerequisite test used the normality test of data distribution. After conducting prerequisite test, the hypothesis test using correlation analysis Product Moment was carried out. Based on the analysis result, it was obtained that $r_{x y \text { cal }}=$ 0,484 . In the significance level of $5 \%$ in which $\mathrm{n}=106$, it was obtained that $r_{x y \text { tab }}=0,195$. As $r_{x y \text { cal }}>$ $r_{x y ~ t a b}=0,484>0,195$, it can be mentioned that $H_{0}$ stating that there is no significant correlation between the interpersonal intelligence and the social science learning achievement in the fifth-grade in Elementary School Gugus IV Abiansemal in the academic year 2017/2018 was rejected and $H_{a}$ was accepted. It can be concluded that there is a significant correlation between the interpersonal intelligence and the social science learning achievement of the fifth-grade students in Elementary School Gugus IV Abiansemal in the academic year 2017/2018. For the result obtained the positive scatterplot of positive correlation, it can be stated that the higher interpersonal intelligence that the students have, the higher social science learning achievement that they will obtain.
\end{abstract}

Keywords: Interpersonal intelligence, learning achievement, social science (IPS). 


\section{Pendahuluan}

Pendidikan merupakan salah satu kebutuhan dasar manusia yang berguna dalam menjalani kehidupannya, melalui pendidikan seseorang dapat mengasah kemampuan mereka untuk mencapai cita-cita yang diinginkan dan mendapatkan kebahagian melalui pengetahuan yang dimilikinya. Hal tersebut sejalan dengan pendapat Ki Hajar Dewantara (1994) yang menyatakan bahwa "pendidikan menuntun segala kekuatan kodrat yang ada pada peserta didik agar sebagai manusia dan anggota masyarakat dapat mencapai keselamatan dan kebahagiaan hidup yang setinggi-tingginya". Pengetahuan tersebut dapat diperoleh melalui proses pendidikan yang memiliki tujuan untuk menciptakan manusia yang cerdas, inovatif, kreatif, dan memiliki budi pekerti yang baik.

Dalam dunia pendidikan tentu melalui suatu proses belajar. Belajar menurut Skinner (dalam Syah, 2009:64) merupakan suatu proses adaptasi prilaku yang bersifat progresif dan membutuhkan waktu untuk mengarah pada keadaan yang lebih baik dari sebelumnya. Selain itu belajar menurut Baharuddin dan Wahyuni (2010:12) "merupakan aktivitas yang dilakukan seseorang untuk mendapatkan perubahan dalam dirinya melalui pelatihanpelatihan atau pengalaman-pengalaman". Dari beberapa pemaparan tersebut maka dapat dipahami secara umum bahwa belajar merupakan suatu proses untuk memperoleh perubahan tingkah laku baik dalam bentuk pengetahuan, sikap, maupun ketrampilan sebagai suatu pengalaman dari apa yang telah dipelajari.

Pada proses pembelajaran tidak luput dari timbulnya suatu masalah, masalah belajar merupakan suatu keadaan yang dialami siswa yang dapat menghambat kelancaran untuk memperoleh suatu perubahan tingkah laku yang baru secara keseluruhan. Beberapa masalah dalam proses pembelajaran yang sering dijumpai pada diri siswa menurut Rice (Shertzer dan Stone, 1974) yaitu kurangnya minat belajar, murung, tingkah laku anti sosial, keterasingan, dll. Hal tersebut sejalan dengan hasil observasi awal yang dilakukan di SD Gugus IV Abiansemal, permasalahan yang kerap terjadi mengenai keterampilan sosial siswa yaitu masih terdapat siswa yang kesulitan dalam bekerja kelompok, cenderung pasif, dijauhi teman, serta kurang mampu berinteraksi dengan guru maupun siswa lain. Strategi pembelajaran kooperatif juga belum optimal diterapkan, hanya beberapa kali dan tanpa memperhatikan keterampilan sosial siswa. Disisi lain perhatian siswa terhadap materi pelajaran yang disampaikan guru belum maksimal sehingga hal tersebut berkaitan dengan hasil belajar siswa.

Hasil belajar merupakan "kemampuan-kemampuan yang dimiliki siswa setelah menerima pengalaman belajarnya" (Sudjana,2004:22), untuk mencapai atau memperoleh pengetahuan yang tercantum melalui hasil belajar yang optimal sesuai dengan kecerdasan intelektual merupakan salah satu tujuan belajar. Sebagian besar orang beranggapan bahwa hasil belajar yang baik hanya dapat diraih oleh siswa yang memiliki kecerdasan intelektual tinggi atau di atas rata-rata. Namun kenyataannya siswa yang memiliki kecerdasan intelektual tinggi belum tentu mampu menunjukkan hasil belajar yang memuaskan sesuai dengan kemampuan yang diharapkan dalam belajar, begitu juga sebaliknya. Hal ini menunujukkan intelegensi/kecerdasan tersebut tidak hanya mencakup satu aspek kognitif saja, melainkan dapat dilihat dari berbagai aspek. Gardner (1983) menyatakan bahwa kecerdasan merupakan kemampuan untuk menangkap situasi baru serta kemampuan untuk belajar dari pengalaman masa lalu seseorang. Kecerdasan bergantung pada konteks, tugas serta tuntutan yang diajukan oleh kehidupan, dan bukan tergantung pada nilai IQ, gelar perguruan tinggi atau reputasi bergengsi. Seorang ahli psikologi tersebut dalam teori Multiple Intellegence (kecerdasan ganda) juga mengemukakan bahwa manusia tersebut setidaknya memiliki sembilan jenis kecerdasan salah satunya adalah kecerdasan interpersonal.

Kecerdasan Interpersonal atau bisa dikatakan sebagai kecerdasan sosial merupakan kemampuan dan keterampilan seseorang dalam menciptakan relasi, membangun relasi baru dan mempertahankan relasi sosialnya sehingga kedua belah pihak berada dalam situasi yang menguntungkan (Safaria,2005:23). Lwin (2008) juga menjelaskan bahwa kecerdasan interpersonal merupakan kemampuan untuk memahami perasaan, suasan hati, keinginan ataupun maksud dari orang lain yang kemudian ditanggapi secara layak. Menurut Gardner 
(dalam Baharuddin \& Esa,2010:150) Kecerdasan interpersonal merupakan kemampuan seseorang untuk mengerti dan menjadi peka terhadap perasaan, motivasi, watak, dan temperamen orang lain. Dari pengertian tersebut dapat di pahami bahwa kecerdasan interpersonal adalah kemampuan untuk mengerti dan memahami maksud atau perasaan orang lain sehingga tercipta hubungan yang harmonis dengan orang lain. Karena pada dasarnya manusia membutuhkan orang lain dalam menjalani kehidupannya.

Kecerdasan interpersonal memiliki peranan penting dalam membantu siswa menyesuaikan diri serta membentuk hubungan sosial. Begitu juga sebaliknya, tanpa kecerdasan interpersonal siswa akan mengalami kesulitan dalam menjalin hubungan dengan orang lain. Terlebih lagi melalui kecerdasan interpersonal memungkinkan siswa untuk berkomunikasi serta bersosialisasi dengan baik dan efektif, karena di era perkembangan zaman siswa diharapkan mampu untuk membangun ilmunya melalui berbagai kegiatan pembelajaran yang bersifat koperatif/kelompok sehingga dapat mengoptimalkan hasil belajarnya. Hal ini tentu memiliki hubungan terhadap hasil belajar siswa, karena untuk mendapatkan hasil belajar yang optimal tidak hanya mencakup aspek kecerdasan intelektual saja, melainkan dari berbagai aspek kecerdasan salah satunya kecerdasan interpersonal. Pendapat tersebut sejalan dengan penelitian yang dilakukan oleh Arjun Fatah Amitha dalam skripsinya yang berjudul " Hubungan Kecerdasan Interpersonal dengan Hasil Belajar pada Mata Pelajaran IPS Kelas V di SD INTIS School Yogyakarta. Pada penelitiannya menyatakan bahwa terdapat hubungan yang signifikan antara kecerdasan interpersonal dengan hasil belajar IPS siswa di SD INTIS School Yogyakarta. Hal ini dapat dideskripsikan, jika kecerdasan interpersonal semakin tinggi maka hasil belajar IPS semakin tinggi pula. Kecerdasan interpersonal siswa juga memberikan kontribusi terhadap hasil belajar IPS.

IImu Pengetahuan Sosial (IPS) merupakan salah satu mata pelajaran di SD yang mengkaji seperangkat peristiwa, konsep, fakta, dan generalisasi yang berkaitan dengan isuisu sosial. Pembelajaran IPS di SD bertujuan mengenalkan konsep-konsep yang berkaitan dengan lingkungan dan kehidupan bermasyarakat, memiliki kesadaran terhadap nilai-nilai sosial dan kemanusiaan, memiliki kemampuan bekerjasama, berkomunikasi serta berkompetisi dalam masyarakat yang majemuk, dan memiliki kemampuan dasar untuk berpikir logis, kritis, rasa ingin tahu yang tinggi, inkuiri, mampu memecahkan masalah dan memiliki ketrampilan dalam kehidupan sosial (Gunawan,2016).

Berdasarkan pemaparan yang telah diuraikan sebelumnya, maka dapat dipahami bahwa tinggi rendahnya hasil belajar siswa berhubungan dengan berbagai aspek kecerdasan, salah satunya kecerdasan interpersonal yang termasuk kedalam salah satu macam kecerdasan majemuk. Adapun tujuan yang ingin dicapai pada penelitian ini yaitu untuk mengetahui korelasi yang signifikan antara kecerdasan interpersonal dengan hasil belajar IPS siswa kelas V di SD Gugus IV Abiansemal tahun pelajaran 2017/2018.

\section{METODE}

Rancangan penelitian ini menggunakan design penelitian ex post facto Penelitian expost facto merupakan sebuah penelitian yang variabel-variabel bebasnya telah terjadi ketika peneliti mulai dengan pengamatan variabel terikat dalam suatu penelitian (Kerlinger dalam Sukardi, 2014). Dari pemahaman tersebut, maka penelitian ini termasuk penelitian expost facto dengan jenis penelitian korelasional atau penelitian hubungan. Hal ini karena penelitian ini dilakukan untuk mengetahui korelasi antara dua variabel tanpa memanipulasi keadaan variabel serta data-data yang ada (Gay dalam Sukardi, 2014:166). Dalam hal ini peneliti berusaha mencari korelasi antara kecerdasan interpersonal dengan hasil belajar IPS siswa kelas V SD Gugus IV Abiansemal tahun pelajaran 2017/2018.

Penelitian ini dilaksanakan di kelas V SD Gugus IV Abiansemal yang terdiri dari 6 sekolah dasar pada semester genap. Keenam sekolah tersebut antara lain SD No. 1 Abiansemal DYC, SD No. 2 Abiansemal DYC, SD No. 3 Abiansemal DYC, SD No. 4 Abiansemal DYC, SD No. 1 Ayunan, dan SD No. 2 Ayunan.

Populasi dalam penelitian ini adalah seluruh siswa kelas V SD Gugus IV Abiansemal, Kabupaten Badung Tahun Pelajaran 2017/2018. Dari data yang diperoleh terdapat siswa 
sebanyak 145 siswa, dan ditentukan jumlah sampel penelitian menggunakan rumus Yamane (2015) dan didapatkan jumlah sampel yaitu 106 siswa.

Selanjutnya, untuk menentukan besar sampel dimasing-masing sekolah dalam penelitian ini menggunakan teknik proportional random sampling. Teknik ini merupakan teknik sampling yang dilakukan untuk lebih menjamin representatif sampel jika ternyata subjek yang terdapat dalam strata atau tiap wilayah tidak sama" (Agung, 2014:76-77). Sejalan dengan hal tersebut Sujarweni (2014) menyatakan teknik ini digunakan bila populasi mempunyai anggota/unsur yang tidak homogeny dan berstrata secara proporsional. Random adalah pengambilan anggota sampel dari populasi yang dilakukan secara acak. Jadi teknik proporsional random sampling adalah tenik pengambilan sampel secara acak dengan memperhatikan proporsi atau perbandingan jumlah siswa di masing-masing kelas. Maka ditentukanlah besar sampel pada masing-masing sekolah dengan menggunakan rumus $n=\frac{\sum x}{\sum N} x$ sampel (Sugiyono, 2012) berikut.

dan didapatkan jumlah sampel pada tiap-tiap sekolah yang dapat dilihat pada tabel

Tabel 1. Penentuan sampel yang digunakan setelah dihitung dan dibulatkan

\begin{tabular}{clll}
\hline No. & Nama Sekolah & P & S \\
\hline 1. SD No. 1 Abiansemal Dauh Yeh Cani & 29 & 21 \\
2. SD No. 2 Abiansemal Dauh Yeh Cani & 9 & 7 \\
3. SD No. 3 Abiansemal Dauh Yeh Cani & 33 & 24 \\
4. SD No. 4 Abiansemal Dauh Yeh Cani & 25 & 18 \\
5. SD No. 1 Ayunan & 22 & 16 \\
6. SD No. 2 Ayunan & 27 & 20 \\
Jumlah & 145 & 106 \\
\hline
\end{tabular}

Penelitian ini memiliki tujuan untuk mengetahui korelasi antara dua variabel. Variabel penelitian merupakan suatu atribut, sifat atau nilai dari orang, objek atau kegiatan yang mempunyai variasi tertentu dan ditetapkan oleh peneliti untuk dipelajari dan ditarik kesimpulan (Sugiyono, 2010). Adapun variabel dalam penelitian ini meliputi dua macam variabel yaitu : Kecerdasan interpersonal sebagai variabel bebas (independent). Variabel ini merupakan variabel yang menjadi sebab perubahannya atau timbulnya variabel dependent (Variabel X). Sedangkan hasil belajar IPS sebagai variabel terikat (dependent). Variabel ini merupakan variabel yang dipengaruhi atau yang menjadi akibat karena adanya variabel bebas (Variabel Y).

Metode pengumpulan data yang digunakan dalam penelitian ini yaitu metode tes non tes. Metode non-tes digunakan untuk mengumpulkan data dari masing-masing variabel penelitian dalam bentuk angket/kuisioner untuk variabel bebas / kecerdasan interpersonal dan pencatatan dokumen untuk variabel terikat / hasil belajar IPS. Angket/kuisioner digunakan untuk menilai sikap atau tingkah laku yang diinginkan oleh peneliti dengan cara mengajukan beberapa pernyataan kepada responden. Kemudian responden diminta memberikan jawaban atau respons dalam skala ukur yang telah disediakan.

Dalam penelitian ini skala ukur pada angket/kuisioner yang digunakan mengacu pada model skala likert yang biasanya digunakan untuk mengukur persepsi atau sikap seseorang. Skala ukur ini biasanya ditempatkan berdampingan dengan pernyataan yang telah dibuat agar responden lebih mudah memberikan jawaban yang sesuai dengan pertimbangan mereka. Responden dianjurkan memilih kategori jawaban yang telah disediakan oleh peneliti, seperti sangat setuju (SS), setuju (S), tidak setuju (TS), dan sangat tidak setuju (STS) dengan memberikan tanda silang $(\sqrt{ })$ pada kolom jawaban yang dirasa sesuai dengan diri responden. Untuk menskor skala kategori likert, jawaban diberi bobot dengan nilai kuantitatif 4, 3, 2, 1 untuk empat pilihan pernyataan positif. Sedangkan empat pilihan pernyataan negatif diberi bobot 1,2,3,4 (Sukardi, 2014). Pada penelitian ini instrumen 
angket/kuisioner yang digunakan diadaptasi dari skala kecerdasan interpersonal yang disusun oleh Safaria (2005). Sedangkan metode pencatatan dokumen digunakan untuk memperoleh data berupa daftar nilai UAS IPS siswa kelas V SD Gugus IV Abiansemal pada semester I tahun pelajaran 2017/2018 yang nantinya dijadikan sebagai indikator hasil belajar IPS siswa. Sebelum dilakukannya penyebaran instrumen, maka terlebih dahulu akan dilakukan uji instrumen penelitian. Dalam penelitian ini dilakukan uji validitas isi dan validitas konsrtuk untuk intrumen yang berupa angket/kuisioner.

Metode analisis data yang digunakan dalam penelitian ini yaitu metode analisis statistik inferensial. Metode analisis statistik inferensial merupakan "suatu cara pengolahan data yang dilakukan dengan jalan menerapkan rumus-rumus statistik inferensial untuk menguji suatu hipotesis penelitian yang diajukan peneliti, dan kesimpulan ditarik berdasarkan pengujian terhadap hipotesis" (Agung, 2014:110). Menurut Sudaryono (2017:349) "statistik inferensial adalah metode analisis yang digunakan untuk menganalisis data sampel dan hasilnya diberlakukan untuk populasi”. Berdasarkan pemahaman tersebut maka dapat disimpulkan bahwa metode analisis statistik inferensial merupakan metode/cara menganalisis data penelitian dengan rumus statistik dan menarik kesimpulan dari data sampel yang akan diberlakukan secara umum.

Analisis data statistik inferensial menggunakan teknik korelasi product moment. . "Teknik korelasi product moment berfungsi untuk menghitung koefisien korelasi antara variabel bebas interval (skor) dengan variabel terikat interval (skor) lainnya" (Agung, 2016:125). Dalam pengujian analisis menggunakan product moment, sebelum melakukan uji hipotesis menggunakan teknik korelasi product moment, maka dilakukan uji prasyaratan. Uji prasyaratan analisis dalam penelitian ini yaitu uji normalitas.

Uji normalitas pada penelitian ini dilakukan mengukur apakah data yang dimiliki mempunyai distribusi normal sehingga dapat dipakai dalam statistik parametik, jika data tidak berdistribusi normal maka dapat dipakai statistik non parametik. "Uji normalitas adalah melakukan perbandingan antara data yang kita miliki dengan data berdistribusi normal yang memiliki mean dan standar deviasi yang sama dengan data yang kita miliki"( Sujarweni,2014:102). Untuk melihat data berdistribusi normal atau tidak, dapat menggunakan Chi Kuadrat $\left(x^{2}\right)$. Kreteria yang digunakan dengan menggunakan taraf signifikan $5 \%$ dan derajat kebebasan $(\mathrm{dk})=\mathrm{k}-1$ adalah jika nilai $\mathrm{x}^{2}$ hitung $<\mathrm{x}^{2}$ tabel maka $\mathrm{H}_{0}$ diterima dan $\mathrm{H}_{\mathrm{a}}$ ditolak yang berarti sebaran data berdistribusi normal, sedangkan jika nilai $\mathrm{x}^{2}$ hitung $>\mathrm{x}^{2}$ tabel maka $\mathrm{H}_{0}$ ditolak dan $\mathrm{H}_{\mathrm{a}}$ diterima yang berarti sebaran data tidak berdistribusi normal (Dantes, 2014).

Uji hipotesis dilaksanakan untuk mengetahui apakah $\mathrm{H}_{\circ}$ yang berbunyi tidak terdapat korelasi yang signifikan antara kecerdasan interpersonal dengan hasil belajar IPS siswa kelas V di SD Gugus IV Abiansemal ditolak atau diterima, maka diperlukan kriteria tertentu dengan nilai tertentu baik dari hasil perhitungan maupun hasil dari tabel yang kedua hasil tersebut dibandingkan. Uji hipotesis pada penelitian ini dilakukan dengan menggunakan teknik korelasi Product Moment.

Dalam pembuktian, hipotesis alternatif $\left(\mathrm{H}_{\mathrm{a}}\right)$ digantikan menjadi $\left(\mathrm{H}_{\mathrm{o}}\right)$ agar peneliti tidak memiliki prasangka sehingga hipotesis yang diuji yaitu hipotesis nihil $\left(\mathrm{H}_{\mathrm{o}}\right)$. Apabila pengujian menerima $\mathrm{H}_{0}$ berarti $\mathrm{H}_{a}$ ditolak, begitu juga sebaliknya. Pengambilan keputusan menggunakan angka pembanding $r_{x y}$ tabel dengan taraf signifikansi $5 \%$ dengan kriteria jika $r_{x y}$

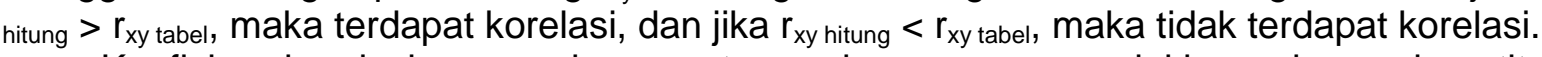

Koefisien korelasi merupakan suatu angka yang menunjukkan ukuran kuantitatif korelasi antara variabel yang dikorelasikan. Angka koefisen korelasi bergerak dari $-1,00$ (negatif 1) sampai dengan $+1,00$ (positif 1 ). Korelasi yang baik adalah korelasi yang baik adalah korelasi yang menunjukan +1 (Agung, 2016). Sependapat dengan hal tersebut Siregar (2015) mengatakan nilai korelasi $r=-1$ artinya korelasi negatif sempurna dan terjadi korelasi bertolak belakang antara variabel $X$ dan variabel $Y$, bila variabel $X$ naik, maka $Y$ turun. Sedangkan apabila $r=1$ artinya korelasi positif sempurna maka terjadi korelasi searah antara variabel $X$ dan variabel $Y$, bila variabel $X$ naik, maka variabel $Y$ naik. 


\section{HASIL DAN PEMBAHASAN}

Data hasil penelitian ini memaparkan mengenai data kecerdasan interpersonal sebagai variabel bebas $(\mathrm{X})$ dan data hasil belajar IPS sebagai variabel terikat $(\mathrm{Y})$ yang ditampilkan dalam grafik.

Berdasarkan penelitian data hasil kecerdasan interpersonal diperoleh nilai tertinggi yaitu 89 dan nilai terendah yaitu 68 dengan rata-rata sebesar 75,63. Data hasil kecerdasan interpersonal dapat dilihat pada grafik berikut.

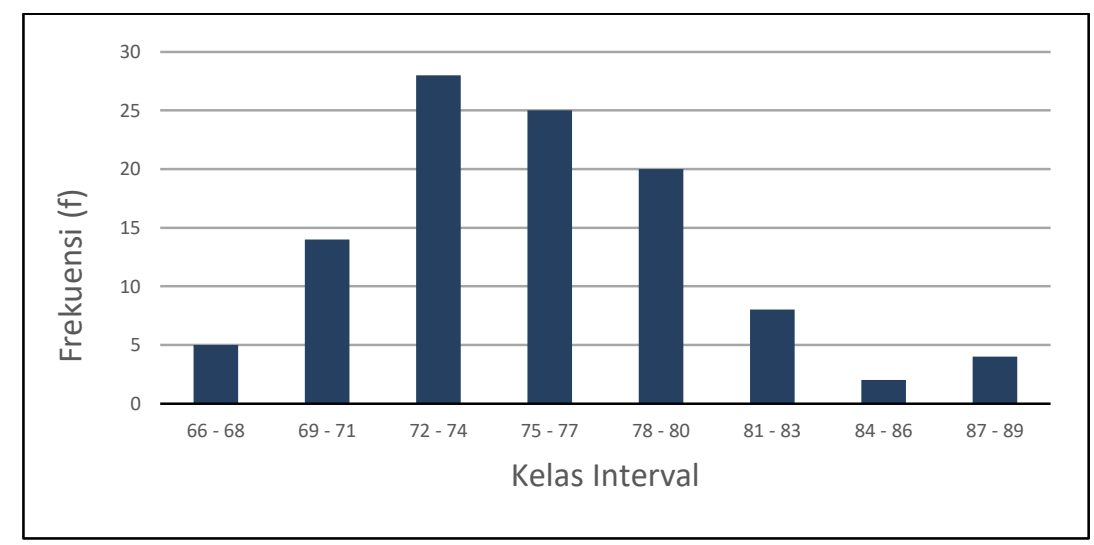

Gambar 1. Histogram Data Kecerdasan Interpersonal

Dari histogram data kecerdasan interpersonal dapat diketahui bahwa frekuensi nilai terbanyak terdapat pada interval ke-3, maka data tersebut dapat dikonversikan dengan cara, membandingkan angka rata-rata dengan kriteria penilaian acuan patokan (PAP) skala 5. Rerata dari kecerdasan interpersonal siswa adalah 75,63 dan nilai tersebut berada pada nilai PAP rentang 65 - 79. Maka dapat disimpulkan bahwa kemampuan kecerdasan interpersonal siswa kelas V di SD Gugus IV Abiansemal tergolong cukup cerdas. Setelah melakukan uji prasyaratan analisis data dengan uji normalitas, diperoleh $\mathrm{x}^{2}$ itung $=5,892$, dan menggunakan taraf signifikan $5 \%$ dengan menggunakan derajat kebebasan 5 , maka diperoleh $\mathrm{x}^{2}{ }_{\text {tabel }}=$ 11,07 . Hal ini menunjukkan bahwa $x^{2}$ hitung $=5,892<x^{2}$ tabel $=11,07$. Karena harga $x^{2}{ }_{\text {hitung }}$ lebih kecil daripada $\mathrm{x}_{\text {tabel, }}^{2}$ maka $\mathrm{H}_{\circ}$ diterima yang berarti sebaran data kecerdasan interpersonal siswa kelas V di SD Gugus IV Abiansemal berdistribusi normal.

Berdasarkan penelitian data hasil belajar IPS diperoleh nilai tertinggi yaitu 90 dan nilai terendah yaitu 76 dengan rata-rata sebesar 82,83. Data hasil belajar IPS dapat dilihat pada grafik berikut.

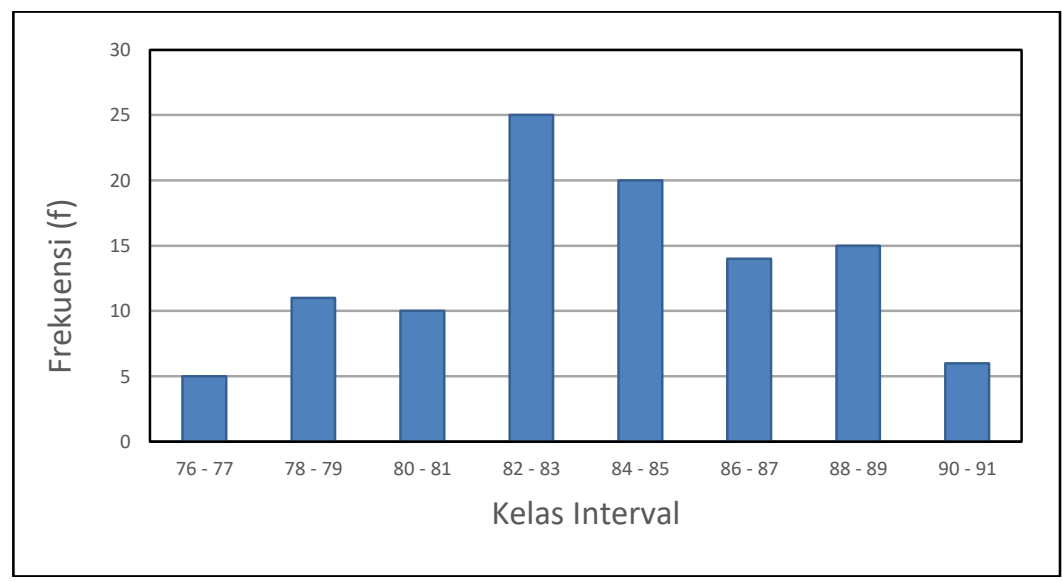

Gambar 2. Histogram Data Hasil Belajar IPS 
Berdasarkan grafik tersebut data hasil belajar IPS dapat diketahui bahwa frekuensi nilai terbanyak terdapat pada interval ke-4, rerata dari hasil belajar IPS siswa adalah 83,82 jika dibulatkan nilai tersebut berada pada nilai PAP rentang 80 - 89. Maka dapat disimpulkan bahwa hasil belajar IPS siswa kelas V SD Gugus IV Abiansemal tergolong baik.

Setelah melakukan uji prasyaratan analisis data dengan uji normalitas, diperoleh $\mathrm{x}^{2}{ }_{\text {hitung }}$ $=7,969$, dan menggunakan taraf signifikan 5\% dengan menggunakan derajat kebebasan 5 , maka diperoleh $x^{2}$ tabel $=11,07$. Hal ini menunjukkan bahwa $x^{2}$ hitung $=7,969<x^{2}$ tabel $=11,07$. Jadi $\mathrm{H}_{0}$ diterima yang berarti sebaran data hasil belajar IPS kelas V di SD Gugus IV Abiansemal berdistribusi normal.

Setelah data diketahui berdistribusi normal, selanjutnya dilakukan uji hipotesis statistik. Uji hipotesis yang dilakukan adalah uji hipotesis dengan teknik menggunakan analisis product moment (variabel $\mathrm{X}$ dengan $\mathrm{Y}$ ). Pengujian hipotesis perlu adanya hipotesis alternatif (Ha), maka untuk tujuan analisis data akan dirumuskan juga hipotesis nol $\left(\mathrm{H}_{0}\right)$, karena dalam statistika yang diuji adalah hipotesis nol $\left(\mathrm{H}_{0}\right)$. Hipotesis yang dirumuskan yaitu hipotesis nol $\left(\mathrm{H}_{0}\right)$ yang berbunyi Tidak terdapat korelasi yang signifikan antara kecerdasan interpersonal dengan hasil belajar IPS kelas V di SD Gugus IV Abiansemal tahun pelajaran 2017/2018.

Pengujian hipotesis penelitian yang menggunakan analisis product moment, yang bertujuan untuk mengetahui signifikansi korelasi kecerdasan interpersonal dengan hasil belajar IPS siswa dengan menggunakan rumus sebagai berikut.

$\mathrm{r}_{\mathrm{xy}}=\frac{\mathrm{N} \sum \mathrm{XY}-\left(\sum \mathrm{X}\right)\left(\sum \mathrm{Y}\right)}{\sqrt{\left[\mathrm{N} \sum \mathrm{X}^{2}-\left(\sum \mathrm{X}\right)^{2}\right]\left[\mathrm{N} \sum \mathrm{Y}^{2}-\left(\sum \mathrm{Y}\right)^{2}\right]}}$

(Suharsimi. 2015:

Keterangan:

$r_{x y}=$ koefisien korelasi

$\mathrm{N}=$ jumlah subjek

$\mathrm{X}=$ skor item

$\mathrm{Y}=$ skor total

$\sum X=$ jumlah skor item

$\sum Y=$ jumlah skor total

$\sum X^{2}=$ jumlah kuadrat skor item

$\sum Y^{2}=$ jumlah kuadrat skor total

$X$ sebagai data dari variabel independent (variabel bebas)

Y sebagai data dari variabel dependent (variabel terikat)

Hasil analisis product moment bisa dilihat pada tabel 2 .

Tabel 2. Analisis Product Moment

\begin{tabular}{cc}
\hline$\sum \mathbf{X}$ & 8016 \\
\hline$\sum \mathbf{Y}$ & 8887 \\
$\sum \mathbf{X}^{2}$ & 608554 \\
$\sum \mathbf{Y}^{2}$ & 746495 \\
$\sum \mathbf{X Y}$ & 672943 \\
$\mathbf{r}_{\mathbf{x y ~ h i t u n g}}$ & 0,484 \\
$\mathbf{r}_{\mathbf{X y ~ t a b e l}}$ & 0,195 \\
\hline
\end{tabular}


Berdasarkan tabel tersebut, Setelah dilakukan pengujian untuk menentukan koefisien korelasi dengan menggunakan rumus pearson product moment diperoleh hasil $r_{x y}$ hitung $=$ 0,484 . Untuk menguji signifikansi koefisien korelasi, digunakan nilai tabel product moment $\left(r_{x y}\right.$ tabel $)$ untuk $\mathrm{n}=106$ pada taraf signifikansi $5 \%$ diperoleh nilai $r_{x y}$ tabel adalah 0,195 . Maka dapat dinyatakan $r_{x y \text { hitung }}=0,484>r_{x y}$ tabel $=0,195$ dan ini berarti nilai $r_{x y}$ hitung signifikan dengan nilai 0,484 sehingga $\mathrm{H}_{0}$ yang menyebutkan tidak terdapat korelasi yang signifikan antara kecerdasan interpersonal dengan hasil belajar IPS siswa kelas V SD Gugus IV Abiansemal tahun pelajaran 2017/2018 ditolak, dan $\mathrm{H}_{\mathrm{a}}$ diterima.

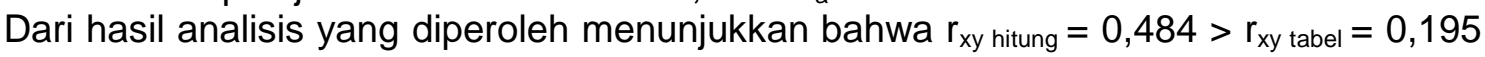
sehingga $\mathrm{H}_{\mathrm{a}}$ yang menyatakan terdapat korelasi yang signifikan antara kecerdasan interpersonal dengan hasil belajar IPS siswa kelas V di SD Gugus IV Abiansemal tahun pelajaran 2017/2018 diterima. Dari uraian tersebut dapat diinterpretasikan bahwa rata-rata siswa yang tergolong memiliki kecerdasan interpersonal tinggi diikuti dengan hasil belajar IPS yang cukup baik, tingkat hubungan antara kedua variabel juga tergolong cukup/sedang dengan rentang 0,40 - 0,599. Arah korelasi yang positif menunujukkan rata-rata siswa yang tergolong memiliki kecerdasan interpersonal tinggi dapat meningkatkan dan menunjukkan hasil belajar IPS yang tinggi pula.

Keberhasilan siswa untuk memperoleh hasil belajar IPS yang baik dipengaruhi oleh faktor kecerdasan salah satunya kecerdasan interpersonal. Siswa yang memiliki kecerdasan interpersonal yang tinggi akan mampu menjalin komunikasi yang efektif dengan orang lain, mampu berempati dengan orang lain, mampu mengembangkan hubungan yang harmonis, dapat memahami perasaan, maksud dan tujuan orang lain sehingga dapat memberikan respon yang tepat dan menciptakan keberhasilan dalam berinteraksi. Semua keterampilanketerampilan yang dikembangkan dalam kecerdasan interpersonal sangat bermanfaat didalam proses belajar, siswa dapat menciptakan pembelajaran yang efektif, inovatif, dan kreatif sehingga proses belajar menjadi lebih optimal dan hasil belajar mendapatkan hasil yang maksimal.

Hal ini sejalan dengan pendapat yang dikemukan oleh Baharuddin \& Wahyuni (2010) yang menyatakan bahwa semakin tinggi tingkat kecerdasan seseorang, semakin besar peluang untuk memperoleh hasil belajar yang baik. Selain itu Amitha (2016) juga mengungkapkan bahwa kecerdasan interpersonal memiliki hubungan dengan hasil belajar IPS, jika kecerdasan interpersonal semakin tinggi maka hasil belajar IPS semakin tinggi pula.

\section{SIMPULAN DAN SARAN}

Berdasarkan hasil analisis data diperoleh nilai $r_{x y}$ hitung $=0,484$ jika dikonfersikan mengenai tingkat korelasi dan kekuatan hubungan koefisien korelasi menunjukkan bahwa terjadi korelasi yang cukup/sedang antara kecerdasan interpersonal dengan hasil belajar IPS siswa kelas V di SD Gugus IV Abiansemal tahun pelajaran 2017/2018. Sedangkan arah korelasi dalam bentuk positif berarti semakin tinggi kecerdasan interpersonal maka semakin tinggi pula hasil belajar IPS siswa.

Dari uraian tersebut maka simpulan dari penelitian ini yaitu terdapat korelasi yang signifikan antara kecerdasan interpersonal dengan hasil belajar IPS siswa kelas V di SD Gugus IV Abiansemal tahun pelajaran 2017/2018. Hal ini ditunjukkan dari nilai $r_{x y}$ hitung $=0,484$ $>r_{x y \text { tabel }}=0,195$ pada taraf signifikasi $5 \%$ dengan $n=106$.

Adapun saran yang disampaikan sebagai berikut. Berdasarkan temuan penelitian yang diperoleh, disarankan kepada guru agar lebih mengembangkan kecerdasan interpersonal siswa melalui pembelajaran yang bersifat kooperatif dan menekankan keterampilanketarmpilan interpersonal yang terkandung didalam mata pelajaran IPS sehingga dalam hal ini siswa dapat mengembangkan sikap empati, mampu berkomunikasi secara efektif, membangun relasi/hubungan dengan orang lain yang nantinya bermanfaat dalam proses belajarnya dan dapat memaksimalkan hasil belajar siswa.

Berdasarkan temuan penelitian yang diperoleh, disarankan kepada siswa untuk lebih aktif didalam proses pembelajaran, dan menanamkan keterampilan-keterampilan interpersonal dalam diri seperti kemampuan berkomunikasi secara efektif, memahami maksud orang lain, memiliki sikap empati dan mampu mendengarkan dengan baik, karena 
dengan memiliki kecerdasan interpersonal yang tinggi akan membantu proses pembelajaran menjadi lebih optimal sehingga dapat meningkatkan hasil belajar siswa khususnya pada mata pelajaran IPS.

Berdasarkan temuan penelitian yang diperoleh, disarankan kepada peneliti lain agar hasil penelitian ini digunakan sebagai referensi untuk melaksanakan penelitian selanjutnya dan semoga penelitian ini bermanfaat bagi seluruh elemen masyarakat yang menggunakan penelitian ini.

\section{DAFTAR RUJUKAN}

Agung, A.A.Gede. 2014. Metodologi Penelitian Pendidikan. Singaraja: Universitas Pendidikan Ganesha.

Agung, A.A.Gede. 2016. Statistika Dasar untuk Pendidikan. Yogyakarta: Deepublish.

Amitha, A.F. 2016. Hubungan Kecerdasan Interpersonal Dengan Hasil Belajar Pada Mata Pelajaran IPS Kelas V di SD Intis School Yogyakarta. Prodi Teknologi Pendidikan. Vol.V Nomor 6.6 UNY. Tersedia pada file:///D:/SKRIPSI\%20DEWA/jurnal\%20dewa/jurnal\%20dewa\%202.pdf (diakses pada tanggal 4 Januari 2018 pukul 14.15 wita).

Amstrong, Thomas. 2002. 7 Kinds of Smart. "Menemukan dan Meningkatkan Kecerdasan Anda Berdasarkan Teori Multiple Intelligence”. Jakarta: Gramedia Pustaka Utama.

Arikunto, Suharsimi. 2010. Prosedur Penelitian: Suatu Pendekatan Praktek. Jakarta: Rineka Cipta.

Arikunto, Suharsimi. 2015. Dasar-Dasar Evaluasi Pendidikan. Jakarta: Bumi Aksara

Azwar, S. 2004. Metode Penelitian. Yogyakarta : Pustaka Pelajar.

Baharuddin, H \& Esa Nur Wahyuni. 2010. Teori Belajar \& Pembelajaran. Cetakan Ke-5. Yogjakarta: Ar-Russ Media.

Dantes. N. 2014. Analisis dan Desain Eksperimen. Singaraja: Program Pasca Sarjana Undiksha.

Dantes. N. 2017. Desain Eksperimen dan Analisis Data. Depok: Rajawali Pers.

Gardner, Howard. 2003. Multiple Intelligence: Kecerdasan Majemuk Teori dalam Praktek. Batam: Interaksara.

Gunawan, Rudy. 2016. Pendidikan IPS: Filosofi, Konsep dan Aplikasi. Bandung: Alfabeta.

Kamus Besar Bahasa Indonesia [online]. https://kbbi.kemdikbud.go.id/entri/cerdas. diunduh pada tanggal 9 Januari 2018 pukul 15.05 WITA.

Kamus Besar Bahsa Indonesia [online]. https://www.google.co.id/amp/s/kbbi.web.id/cerdas.html. Diunduh pada tanggal 20 maret 2018 pukul 17.29 WITA.

Lwin, May. 2005. Cara Membangkitkan Berbagai Komponen Kecerdasan. Jakarta : Gramedia.

Lwin, May. 2008. Cara Mengembangkan Berbagai Komponen Kecerdasan. Jakarta: Indeks.

Pendidikanku.org. 2016. Pengertian Kecerdasan dan Macam-macam Kecerdasan. http://www.pendidikanku.org/2016/09/pengertian-kecerdasan-dan-macam-macam.html Diunduh pada tanggal 9 Januari 2018 pukul 15.31 WITA.

Prani, Astaga. 2015. Peningkatan Kecerdasan Interpersonal Menggunakan Metode Diskusi Kelompok Dalam Pembelajaran Ips Pada Siswa Kelas IV SD Negeri Kenaran 2 Prambanan. S1 Thesis, PGSD, UNY. Tersedia pada 
http://eprints.uny.ac.id/14828/2/BAB\%20II.pdf (diakses pada 14 Januari 2018 pada pukul 13.35).

Riduwan \& Akdon. 2007. Rumus dan Data dalam Analisis Statistika. Bandung: Alfabeta.

Safaria, T. 2005. Interpersonal Intelligence: Metode Pengembangan Kecerdasan Interpersonal Anak. Yogyakarta: Amara Books.

Siregar, Sofian 2015. Stastiska Terapan untuk Perguruan Tinggi Edisi Pertama. Cetakan Pertama. Jakarta: Kencana Prenada Media Group.

Siregar, Sofian 2017. Stastiska Terapan untuk Perguruan Tinggi. Jakarta: Kencana Prenada Media Group.

Sudaryono. 2016. Metode Penelitian Pendidikan. Jakarta: Prenadamedia Group.

Sudjana, Nana. 2004. Dasar-dasar Proses Belajar Mengajar. Bandung: Sinar Baru Algensido Offset.

Sugiyono. 2010. Metodologi Penelitian Pendidikan Pendekatan Kuantitatif, Kualitatif, dan $R \& D$. Bandung : Alfabeta.

Sugiyono. 2014. Metodologi Penelitian Pendidikan. Bandung: Alfabeta Bandung.

Sujarweni, V.W. 2014. Metodologi Penelitian. Yogyakarta: Pustaka Baru Press.

Sukardi. 2014. Metodologi Penelitian Pendidikan. Jakarta : Bumi Aksara.

Sumarni, Sri. 2012. Metodelogi Penelitian Pendidikan. Yogyakarta: Insan Madani.

Syah, Muhibbin. 2003. Psikologi Belajar. Jakarta : Rajawali Pers.

Syah, Muhibbin. 2009. Psikologi Belajar. Jakarta : Rajawali Pers.

Widayat, A. 2017. 14 Agustus. "Negara Maju Karena Kualitas SDM". Media DJKN, hImn.1. Tersedia pada https://www.djkn.kemenkeu.go.id/berita media/baca/12514/Negara-MajuKarena-Kualitas-SDM.html (diakses pada tanggal 7 Januari 2018 pukul 14.11 wita).

Yaumi, M. 2012. Pembelajaran Berbasis Multiple Intelligences. Jakarta: Dian Rakyat. 